\section{Traditional Elements in the Iranian Realistic Drama}

Farindokht Zahedi ${ }^{1}$

University of Tehran

\begin{abstract}
Modern Iranian drama developed in line with a liberal school of thought, both before and after the Constitutional Revolution in 1906. It came during the transition from a traditional to a new type of society that was able to tolerate and accept the revolution. The arrival of European theatre in 1878, with its dependence on a written text rather than improvisatory acting, was part of the modernization process in Iran that enjoyed its height in the early years of the twentieth century. At the same time, traditional theatre was being rediscovered, and playwrights started using some of its forms to develop indigenous modern Iranian theatre to meet the standards of the genuine past and dynamic present. Although there was an assimilation of certain secular tendencies, the newly appearing type of drama satisfied the need for modernity through defending political and social liberties. The road to transition began in the 1850's and gained momentum during the 1940's through the 1970's, leaving its effects on Iranian drama in such a way that its legacy persists to date.
\end{abstract}

Keywords: realistic drama; Iranian drama; Iran Constitutional Revolution

\begin{abstract}
Abstrak
Drama Iran modern berkembang sejalan dengan aliran pemikiran liberal, baik sebelum dan sesudah Revolusi Konstitusi pada tahun 1906. Itu terjadi selama transisi dari tradisional ke masyarakat tipe baru yang mampu mentolerir dan menerima revolusi. Kedatangan teater Eropa pada tahun 1878, dengan ketergantungannya pada teks tertulis dan bukan akting improvisasi, adalah bagian dari proses modernisasi di Iran yang menikmati puncaknya pada tahun-tahun awal abad kedua puluh. Pada saat yang sama, teater tradisional sedang ditemukan kembali, dan penulis naskah mulai menggunakan beberapa bentuknya untuk mengembangkan teater tradisional Iran modern untuk memenuhi standar masa lalu yang asli dan masa kini yang dinamis. Meskipun ada asimilasi kecenderungan sekuler tertentu, jenis drama yang baru muncul memuaskan kebutuhan akan modernitas melalui pembelaan kebebasan politik dan sosial. Jalan menuju transisi dimulai pada tahun 1850-an dan memperoleh momentum selama tahun 1940 hingga 1970-an, dengan meninggalkan efeknya pada drama Iran, sehingga warisannya tetap ada hingga saat ini.
\end{abstract}

Kata kunci: drama realistis; drama Iran; Revolusi Konstitusi Iran
DANC官

jurnal tari, teater, dan wayang volume 1 number 2 ,

November 2018

page $59-64$

\section{Introduction}

The revolutionary processes of Iranian contemporary drama as a series of expressive cultural activities was in pace with Iran's transition from a traditional to a modern society, modified or modulated itself to meet the needs brought about by striking sociocultural changes.

In the years of 1940 to 1979, a paradoxical situation emerged: on the one hand, the unsuccessful Westernization

$\overline{1}$ Correspondence: University of Tehran. Ph.: +982166739812/+989126973981. E-mail: farinzahedi@gmail. com. 
process was rapidly coming to an inglorious end, while on the other hand, there were official attempts to rekindle a national and cultural identity by reviving the traditional heritage. The dramatists of this era were not merely preoccupied by teaching their audiences; rather they would portray social matters with an analytical brush and seek an authentic identity that was threatened by the superficially imposed identity designed for the sake of politics. Therefore they tried to expose the truth by revealing the existing realities hidden in social and political events. Meanwhile, their plays contained their own hidden messages that were derived from international and national topics. The preservation of an authentic Iranian identity was the main preoccupation of playwrights during this era.

In some works the basic elements of Iranian processional theatre (ta'ziyeh) and traditional storytelling (naghali) which had prevailed in Persian literature for a long period of time, happened to mix readily with the Western theatre techniques to form a new style in playwriting. The result was a simultaneous impact on two different groups of writers and artists with diverse outlooks and styles. They began to experiment with different approaches to dramatic plays and productions; they either produced plays inspired by the modern drama in terms of the ways of Western structuring, characterization and plot making to link the stage and real life through the realistic plays as a modern means of communication, or chose to remain faithful to the accepted norms of traditional theatre. The dynamism of naghali (storytelling) and ta'ziyeh, the two major Iranian popular performing art forms, took precedence above all else and functioned as the driving force in creating new styles for playwriting. Both forms had special facets which gave shape to the new styles of playwriting. Regardless of stylistic differences, the thematic aim of both types of plays served as a confirmation of cosmological or individualistic criteria described through either an objective-logical or subjective- poetical mode of expression.
A variety of new plays with new styles attempted to capture the essence of modern life by expressing the relationship between the individual and society. Plays became the means of exposing social controversy. However, their method of posing questions and providing answers appeared in different styles, and the aesthetic response was different according to the cultural and social contexts of the time.

Before describing the new syntactic structure of drama, a brief introduction to ta'ziyeh and naghali may be noteworthy. Ta'ziyeh is a passion drama depicting the martyrdom of the central religious figure in Shi'a Islam, Imam Hosein. It focuses on ritual mourning for Imam Hosein, grandson of the prophet Mohammad, and candidate for the leadership of the Muslim community. The story of Imam Hosein's death in Shi'a Muslims belief is occupying approximately the same symbolic importance as the resurrection of Christ occupies in Christianity. Imam Hosein's death at the hands of the Sunni Caliph Yazid, after having been trapped with his family and supporters with limited food and water near Baghdad, is a story of great tragedy on an epic level. Each of the first ten days of Muharram is the occasion for the staging of different performances depicting the death of each of the relatives and supporters of Imam Hussain. Classically on the day of Âshurâ, the tenth day of Muharram, a continuous performance of all the martyrs' deaths is presented in a single recounting.

Ritual mourning for Imam Hossein developed over many centuries. Perhaps the earliest forms of ta'ziyeh were simple recitations of the story of his death accompanied by lamentation. These ceremonies included chanting and simple public processionals is dated back to the fifteenth century, but the first evidence of a fully dramatic form of ta'ziyeh performance was recorded in the late 18th Century during the Afshar dynasty in southern Iran. Ta'ziyeh continues to be performed in Iraq, southern Lebanon, and Bahrain where large Shiite populations exist. The Processional forms of this drama are also seen in India, Pakistan and 
even places far removed from Asia where Shi'a Muslim populations exist - such as Jamaica, although full dramatic performances exist only in Iran. According to Matthew Arnold's note on ta'ziye: "Ta'ziyeh departs from the limits of what is revealed and appointed to be taught as truth" and "...keeps growing under the pressure of the actor's imagination and emotion of the public and receive new developments every day" (1971, p. 389).

Ta'ziyeh plays share with their Christian counterpart's similar social arrangements and ritual, processional and dramatic structures and symbolic forms: both are funereal cycles of plays that are based in religious processions. Another major Iranian traditional performing art is Naghali which is a form of epic recitation or dramatic storytelling of Shahnameh, the epic book of Ferdosi, an Iranian poet of the eleventh century. The essential element in this form of art is the narration of important stories from Iranian fables, myths and epics. It is a performance that one person both narrates and plays all the roles and his skill in employing the language is considered as the measure of the actor's competence. The characteristics of this performing art made it a proper form of relating to people, who have communicated through Persian language and its quintessential poetic form throughout the nation's history. The language plays a crucial role within the discourse of Iranian cultural heritage, as playwrights have consistently been tending to accept the importance of it as the manifestation of the nation's thoughts, experiences, and ambitions.

The influence of these traditional forms is experienced in the modern theatrical forms in Iran. Despite the introduction of Western style theatre, the most successful productions of original works by native writers have always contained elements of these traditional performance genres. Although the religious content of ta'ziyeh was not necessarily accepted to many secular writers, the form itself became a treasure-house to the new theatrical technique.

Therefore, Ta'zieh and Naghali became the revered mediums through which historical events were represented in modern times, and they became the foundation of a new theatrical style and the traditional theatre's narrative technique and temporal structure became a vehicle for artists to portray the pressures of modern life through realistic, historical, and social conflicts as a way of providing foundations for their works.

Through the process of establishing a new synthesized style, they experienced diverse techniques which are worth to be rendered briefly as it is today.

\section{Discussion}

The most important characteristic in the new structure was using a sole theme as a particular element of the traditional epic and narrative techniques combined with action, revelations and developing situation conditioned to the nature of the public and the period.

1. The most important characteristic in the new structure was using a sole theme as a particular element of the traditional epic and narrative techniques combined with action, revelations and developing situation conditioned to the nature of the public and the period.

2. Other attempt taken by some dramatists was to employ the rough and unsophisticated exposition of narration to structure the monologue exposition as an introductory prologue, the type of performing technique that corresponds usually to myths and legends already known to the spectators. Consequently, the devices of suspense and the unexpected, common to realistic drama, became needless.

3. Modern elements such as psychological explanation of the characters were replaced by the narration and the alienation techniques common to the traditional performing arts.

4. In the presentation of the new style dramatists used the retrospective technique of ta'ziyeh as an act of remembering the past during the present for both the actors and the audience. 
5. The invented style included announcements and visual captions that interrupted and summarized the action as a device to moderate the passion of the play and help the audience to contemplate the given situation.

6. To compose the new style dramatists borrowed some technical basis from the realistic drama, such as direct and indirect allusions, questions and continuation of the acts, also coincidence and unmotivated happenings used by the intrigue drama to complicate the situation and/or clarify them.

Among the Iranian writers who contributed to playwriting by employing traditional elements of Persian indigenous performing arts to compose a new dramatic style, Bahram Beyza'i is highly recognized. Bahram Beyza'i (1938- ) is a playwright, a film-maker and a theatre historian that started his career early in his youth and has more than twenty plays to his credit. The charming aspect in Beyz'ai's style besides his capability in amalgamation of modern techniques and divers techniques of Persian puppet shows, Taziyeh and Naghali, he interweaves three threads of the avant-garde, the traditional, and the political to express exigent and characteristically Iranian subjects.

This kind of amalgamation created a different style, utilizing the language as the sustaining element to link the traditional drama to the modern. Beyza'i undertook responsibility to employ language as the Iranian artistic conscience which facilitates the understanding of contemporary issues important to the audience. In his configuration of the contrast between inside and outside, Beyza'i uses the epic scale, the claustrophobic atmosphere, the passionate display of emotions, and the themes of intolerance, injustice, confused identity and martyrdom. Utilizing those borrowed symbols from ta'ziyeh and naghali he accomplishes his film scripts, plays and performances with a uniquely Iranian flavor, however the themes are implicitly hidden behind the language due to censorship.
With a scholarly understanding of Iranian and Asian theater, mythology and history, Baizai speaks the visual language of theatre and film, and aims at an aesthetic perfection that communicates his vision to the audience depending on the cultural background of the viewer.

Almost all his plays have been inspired by Persian original techniques and characters; in one of his plays called Three Puppet Plays, the characters come directly from the marionettes and they are patterned after Persian traditional puppet characters. In Four Boxes, also inspired by the puppet theatre technique, he uses four characters, each dressed in traditional colors representing different groups of society and a scarecrow, which comes to life and, for his own safety, puts the four in separate boxes. Sinbad's Eighth

Journey is an allegory inspired by $A$ Thousand and One Nights. Lamentation, is also motivated by formal techniques of Ta'zieh and puppet shows, as well as many others.

But, in reference to one of his works to serve as an example, I would prefer to use one of his films instead of a play due to the film's availability in this conference. The film Travelers, made in 1995, is one of Beyza'i's most recent films using the tradition of ta'ziyeh, the passion play, blending narrative style of naghali with a sophisticated invention of atmosphere to tell the story of a wedding ceremony which turns into a funeral ceremony when the bride's sister and her entire family, who were bringing the old inherited mirror of the family to decorate the wedding table, are killed in a car accident.

The central character of the script is a grandmother, who remains denying the death of her granddaughter and her family. However she lives in the actual time of the trauma, she keeps relating her emotions to the people she loved and keeps gaining strength and liveliness. Through her remaining on the state of denying death, and her insistence on transmitting the funeral ceremony to the wedding ceremony again, she links the ordinary and super-ordinary realities as an interaction of life and death, and becomes the 
symbol of fertility and construction in the film propagating life instead of death.

The performance of the two ceremonies of wedding and funeral includes several events also being performed as rituals. Each ritual such as decorating of the house, setting up the wedding table, distributing cakes and candies over the tables, preparing food for the guests, tailoring the bridal gown, and the transaction from the wedding to the funeral, weeping of the family, encountering of the family with the family of the truck driver whose fault caused the accident, are the rituals that take place one after another in a very condensed way until the end of the film. Each phase is an extension of the previous phase irrespective of an independent ritual. At the end of the film, as the grandmother refuses to acknowledge the death of the family members, the departed souls arrive to the ceremony with a mirror in the sister's hand bringing to the wedding as a symbol of life and the adjoin of the generations, the same mirror that did not break in the accident due to the nature of its glow and luminosity. As the mythical resurrection of the dead takes place, the bride changes her black clothes to the bridal gown and the film ends in a cyclic form of a ritual celebrating life over the death. The grandmother's endeavor to reject the funeral and death and carry on with the wedding and continuation of life is the same endeavor that Esther makes to bring Tammuz back to life, or as Orpheus journeys to the underworld to bring back Eurydice to the earth, and as Jesus resurrects to fulfill human aspiration to overcome death. This same universal theme is celebrated as rituals in many cultures.

This work of Beyza'i as well as many other works of him are ritualistic performances of life, tracing out in mythical terms a complete cycle of love, happiness, devotion, suffering, death and transcendence. The sense of universalism in Beyza'i's works rests on the politics of identity which usually ascribes the meaning of collective experiences to diverse individuals. Although Beyza'i's general outlook towards human life is philosophical and universal, a strong sense of nationalism seems to pervade his works. Employing Persian traditional elements such as pre-Islamic mythology, archaic language, traditional dramatic forms, and history, Beyza'i establishes a series of foundations which are essential to self-certainty and, therefore, to the identity of a society. He revitalizes the unchangeable logic that is typical of the ritualistic performances as well as the antique tragedies, but the curse does not occur through gods and halfgods that relentlessly lead the individuals towards their doom and death, but a curse from their own past. His works are concerned with tracing out the pattern of action that not only realistically but also mythically and ritualistically complete. Beyza'i refrains of using traditional Western techniques of playwriting in which the realistic depiction of life is being carefully worked out through plot development and characterization. He also rejects the use of rational setting of dialogues as one of the common techniques of expression in well-made plays.

Beyza'i expresses a sort of abstract realism in which the causal connections are defined without reference to space and time. Like a realistic writer, he distinguishes the most important aspects and deals with complex subjects, but avoids the details of the acts. The subjects are being used as the inspiration, the means, but not the end. In fact, through this new style Beyza'i invites his audience to participate and communicate freely with the stage by synthesizing his works out of complex substance with artistic economy in a simple form.

\section{Conclussion}

Through the influence of traditional forms experienced in modern theatrical forms in Iran, the most successful productions of original works by native writers emerged as a new genre of dramatic literature. Ta'zieh and Naghali became the revered mediums through which historical events were represented in modern times, and they became the foundation of a new theatrical style and the traditional theatre's narrative technique and temporal structure became a vehicle for artists to 
portray the pressures of modern life through realistic, historical, and social conflicts as a way of providing foundations for their works.

The most important characteristic in the new structure was using a sole theme, employing the rough and unsophisticated exposition of narration to structure the monologue exposition as an introductory prologue, psychological explanation of the characters were replaced by the narration and the alienation techniques common to the traditional performing arts, they also used the retrospective technique of ta'ziyeh as an act of remembering the past during the present for both the actors and the audience. In the new style they invented style included announcements and visual captions to interrupted and summarized the action and composed the some technical basis from the realistic drama, such as direct and indirect allusions, questions and continuation of the acts, also coincidence and unmotivated happenings used by the intrigue drama to complicate the situation and/or clarify them.

\section{References}

Arnold, Matthew. (1871). 'A Persian Passion Play', The Cornhill Magazine, no. 24.

Ashoori, Dariush. (1996). Ma va Moderniteh (We and Modernity). Tehran: Nashr-e Sarat.

Athary Maryan, Seyed Assadollah. (2000). 'Challenge between Tradition and Modernity in Iran', Iranian Quarterly, vol. 2.
Beeman, William 0. (1982). Culture, Performance, and Communication in Iran. Tokyo: ICLAA.

Bentley, Eric. (1953). In Search of Theatre. New York: Knopf.

Beyza'i, Bahram. (1996). 'Iranian Cinema, from the Past to the Present', Iran Nameh IV: 3. Special Issue on Iranian Cinema.

Boroujerdi, Mehrzad. (1996). Iranian Intellectuals and the West. Syracuse: Syracuse University Press.

Enayat, Hamid. (1973). 'The Politics of Iranianology', Iranian Studies, vol. 6, no.1.

Fani, Kamran. (2001). 'Tarjomeh, chap va Nashr-e ketab dar Iran' (Translation, Print and Publication in Iran) In: Iran va Modernite: Goftegoohay-e Ramin Jahanbeglou (Iran and Modernity: Interviews by Ramin Jahanbeglou). Tehran: Nashr-e Goftar.

Ghaffary, Farrokh. (1984). 'Iranian Secular Dramas'. In: Stanley Hochman (ed.), McGraw-Hill Encyclopedia of World Drama - an International Reference book in 5 volumes, 2 nd ed.

Ghanoonparvar, M.R. (1984), Prophets of Doom: Literature as a Socio-Political Phenomenon in Modern Iran. Lanham: University Press of America.

Gavin, Hambly. (1964). 'Attitudes and Aspirations of the Contemporary Iranian Intellectual', Journal of the Royal Central Asian Society, vol. 50.

Hobsbawm, Eric \& Ranger, Terence (eds.) (1983), The Invention of Tradition. Cambridge: Cambridge University Press 